\title{
THE MEANING OF SYIMBOL IN PENCAK SILAT PERFORMANCE OF TRIBE WEDDING EVENT
}

\section{MAKNA SIMBOL DALAM PERTUNJUKAN PENCAK SILAT PADA ACARA PERNIKAHAN SUKU}

\author{
Marlina, Sapta Sari, Bayu Risdiyanto \\ Program Studi IImu Komunikasi Fakultas IImu-IImu Sosial \\ Universitas Dehasen Bengkulu
}

Email: marlina@gmail.com , sapta.sari26@gmail.com, bayu.risdiyanto@unived.ac.id

How to Cite :

Marlina, Sapta Sari, Bayu Risdiyanto (2020). THE MEANING OF SYIMBOL IN PENCAK SILAT

PERFORMANCE OF TRIBE WEDDING EVENT. Vol. 1 No. 22020 page: 61- 73,

DOI:https://doi.org/10.37638/sengkuni.1.2.61-73

\section{ARTICLE HISTORY}

Received [xx Monthxxxx]

Revised [xx Month $x x x x$ ]

Accepted [xx Month $x x x x]$

\section{KEYWORDS}

OnlineMedia,Conglomeration, News, Editor

This is an open access article under the $C C-B Y-S A$ license

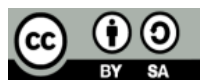

\section{ABSTRAK}

Penelitian ini bertujuan untuk mendiskripsikan makna simbol pertunjukan dalam Pencak Silat upacara adat perkawinan pada masyarakat Desa Tengah Padang kecamatan Talang Empat Kabupaten Bengkulu Tengah. Penelitian ini adalah penelitian kualitatif dimana data yang dikumpulkan berupa kata-kata, gambar, dan bukan angka-angka. Pelaksanaan penelitian dilakukan di Desa Tengah Padang kecamatan Talang Empat Kabupaten Bengkulu Tengah. Pengumpulan data dilaksanakan melalui observasi, wawancara, dan dokumentasi. Instrument dalam penelitian ini adalah peneliti sendiri, yaitu peneliti merencanakan, melaksanakan penelitian, serta melakukan pengumpulan data, menganalisis, menyajikan data, serta menarik kesimpulan. Pencak silat pada awal mulanya kita kenali sebagai perwujudan ilmu beladiri praktis dan seni pertunjukan. Di Desa Tengah Padang Kecamatan Talang Empat Pencak Silat ini, dipertunjukkan sebagai hiburan mana kala keluarga hendak megadakan upacara Pernikahan Dan Acara Resmi, Masyarakat mempertunjukan Seni Pencak Silat Khas Suku Lembak dalam acara saat upacara pernikahan adat Suku Lembak berlangsung. Bentuk penyajian Pencak Silat meliputi ragam gerak Pencak Silat diri atas gerak pembuka Seni Pencak Silat, Gerak Tarian Persembahan, Pedang, Serunai, Kelentang dan Rabana. Makna simbol yang terdiri dari gerak pembukah mengandung makna sikap keterbukaan yang harus dimiliki seseorang.

\section{ABSTRACT}

This study aims to describe the meaning of the symbol of the performance in Pencak Silat traditional marriage ceremonies in the people of Desa Tengah Padang, Talang Empat sub-district, Bengkulu Tengah Regency. This research is a qualitative study in which the data collected are in the form of words, pictures, and not numbers. The research was 

carried out in the Central Village of Padang, Talang Empat
sub-district, Bengkulu Tengah Regency. Data collection is
carried out through observation, interviews, and
documentation. The instrument in this study is the researcher
himself, that is, the researcher plans, conducts the research,
and collects data, analyzes, presents data, and draws
conclusions. Pencak silat was originally recognized as an
embodiment of practical martial arts and performance art. In
the Central Village of Padang, Talang Empat Pencak Silat
Subdistrict, it was shown as an entertainment when the family
wanted to hold a wedding and an official event, the
community performed the traditional Pencak Silat art in the
event "when the Lembak tribal wedding ceremony took place.
The forms of presentation of Pencak Silat include various
movements of Pencak Silat themselves over the opening
movements of Pencak Silat Art, Offering Dance Movements,
Swords, Flavors, Spells and Rabana. The meaning of the
symbol consisting of the act of forming implies an attitude of
openness that must be possessed by someone..

\section{PENDAHULUAN}

Indonesia memiliki banyak suku bangsa dengan perbedaan-perbedaan kebudayaan, yang tercermin pada pola dan gaya hidup masing-masing. Budaya juga merupakan identitas bangsa yang harus dihormati dan dijaga serta perlu dilestarikan agar kebudayaan tidak hilang dan bisa menjadi warisan anak cucu kelak. Secara geografis, wilayah Indonesia dapat dikatakan memiliki wilayah yang sangat luas. Indonesia dikenal sebagai negara kepulauan, yang sebagian besar wilayahnya terdiri dari berbagai pulau yang terbentang dari Sabang sampai Merauke.

Setiap pulau yang ada di Indonesia memiliki etik yang memunculkan corak budaya yang berbeda-beda. Keanekaragaman tersebut membuat indonesia menjadi daya tarik bagi bangsa lain dari belahan dunia. Bahkan tidak sedikit orang mancanegara ingin mempelajarinya karena selain beraneka ragam budaya dan kesenian tradisional. Kebudayaan pada saat ini telah mengalami banyak perubahan dari masa ke masa. Perubahan tersebut akibat munculnya beragam pemikiran dan gagasan oleh masyarakat yang pada dasarnya memiliki sifat kreatif guna mengembangkan kebudayaan tersebut kearah yang lebih baik dan sempurna.

Kesenian Pencak Silat yang terdapat pada Masyarakat Desa Tengah Padang tidak hanya berpungsi sebagai ekspresi seni, melainkan juga aktualisasi dari religiusitas masyarakat baik terhadap Tuhan maupun para nenek moyang melalui gerakan-gerakan silat yang sangat identik dengan sifat pejuang. Secara umum pertunjukan kesenian Pencak Silat dapat digunakan sebagai media untuk mengungkapkan rasa syukur atas suatu peristiwa penting seperti pernikahan, khitanan, dan lain sebagainya. Dalam kenyataannya kesenian Pencak Silat ini adalah warisan budaya nenek moyang oleh 62 | Marlina, Sapta Sari, Bayu Risdiyanto, MAKNA SIMBOL DALAM PERTUNJUKAN PENCAK SILAT PADA ACARA 
masyarakat pendukungnya dan nilai-nilai tradisi yang terdapat pada kesenian Pencak Silat menjadi semakin pudar Padahal kesenian ini adalah salah satu dampak dari adanya arus globalisasi atau perkembangan zaman yang semakin maju.

Di dalam sebuah pertunjukan Pencak Silat dalam Suku Lembak ini setiap gerakan yang dilakukan yaitu mempunyai makna tersendiri seperti menunduk kepala berarti meminta restu agar pertunjukan pencak silat berjalan dengan lancar dan sukses, kaki diinjit dan tangan memegang pedang sambil di goyanggoyang supaya lawan mengetahui bahwa lawan satunya menentang untuk lawan bias menangkis dan lain-lain. Alat-alat yang di gunakan untuk pencak silat yakni Pedang, Rabana, Serunai ,Lemoai, tikar dandan dan kelentang. Suku Lembak adalah suku bangsa yang pemukimannya tersebar di kota bengkulu, terutama di kabupaten bengkulu tengah, Suku Lembak juga mendiami wilayah daerah kota Lubuk Linggau dan Kabupaten Musi Rawas yang berada di wilayah provinsi sumatera selatan. Jumlah Populasi yang bersuku lembak di desa tengah padang ini berjumlah sekitar 1.319 Jiwa, Ratarata beragama islam, (2017-2018) kelompok etnik terdekatnya yaitu: Suku rejang suku serawai, dan suku jawa. Suku lembak terbagi menjadi 2 (dua) bagian, yaitu Lembak Beliti dan Lembak Delapan. Suku lembak Delapan memiliki bagian adat istiadat seperti adat pernikahan.

Berdasarkan pemaparan di atas, penulis tertarik untuk melakukan penelitian lebih lanjut melalui penelitian dengan judul skripsi Makna Simbol Dalam Pertunjukan Pencak Silat Pada Acara Pernikahan Suku Lembak di Kecamatan Talang Empat Kabupaten Bengkulu Tengah yang terletak di Desa Tengah Padang. Penelitian ini ingin mengetahui Makna Simbol Dalam Pertunjukan Pencak Silat pada Aara Pernikahan Suku Lembak di Desa Tengah Padang Kecamatan Talang Empat Kabupaten Bengkulu Tengah.

\section{LANDASAN TEORI}

\section{Makna}

Menurut Ferdinand deSaussure (dalam abdul Chaer,1994:286) mengungkapkan gagasan makna sebagai makna atau konsep yang dimiliki atau yang terkandung dalam tanda linguistik. Makna adalah Hubungan antara symbol suara dengan referensi. Makna Simbolik Simbol dan makna merupakan dua unsur yang berbeda, tetapi saling berkaitan bahkan saling melengkapi. Simbol berasal dari bahasa Yunani yaitu symbolis yang berarti tanda atau ciri yang memberitahukan sesuatu hal kepada seseorang (Endraswara, 2006: 171). Langer (Budiono, 2008: 63) berpendapat bahwa simbol adalah wahana bagi konsepsi manusia tentang objek.

Simbol akan membantu menjelaskan secara benar nilai yang ada dalam masyarakat dan akan menghilangkan keraguraguan tentang kebenaran sebuah penjelasan (Turner, 1967: 9).atau makna mengandung pengertian tentang arti atau maksud suatu kata (Poerwadarminta, 1976: 947, 624). Makna berasal dari hubunganhubungan dari konteks dimana tanda terletak. Suatu tanda yang ada mempunyai macam arti yang berbeda tergantung konteks dimana tanda itu berada (Saussure, 2010: 245). Seperti halnya dalam karya seni tidak 
merumuskan arti namun merumuskan maknanya. Makna seni dirasakan sebagai sesuatu di dalam karya ( Langer, 2006: 147).

Simbol merupakan bentuk yang mengandung maksud, sedangkan makna adalah isinya. Antara simbol dan makna merupakan dua unsur yang berbeda tetapi saling berkaitan dan saling melengkapi, dengan demikian makna simbolik adalah makna yang terkandung dalam suatu keadaan yang merupakan pengantar pemahaman.

\section{Simbol}

Pengertian Simbol yaitu sesuatu yang di ciptakan oleh manusia dan secara konvensional digunakan bersama,teratur, dan benar-benar dipelajari sehingga member peringatan hakikat, manusia,yaitu suatu kerangka yang penuh dengan arti untuk mengorientaskan dirinya kepada yang lain, kepada lingkungan dan kepada dirinya sendiri, sebagai hasil kebudayaan yang syarat makna dan nilai, dapat disebut sebagai sistem simbol. Sehubungan dengan hal itu sebagai sistem simbol yang merupakan representasi mental dari subjek dan wahana konsepsi manusia tentang sesuatu pesan yang diresapkan. (Sumandiyo Hadi, 2006: 22)

Di dalam menginterpretasi simbol dan makna suatu fenomena kebudayaan yang ada dalam masyarakat khususnya masyarakat Suku Lembak sebenarnya tetaplah mendapat tempat tersendiri dan menjadibagian terpenting. Analisis simbol justru akan mampu mengungkap makna di balik fenomena real dan abstrak. Sebab, tanpa sebuah interpretasi yang diungkap dalam sebuah penelitian, sesungguhnya simbol dan makna tersebut menjadi berkadar lemah. Paling tidak akan memunculkan pemahaman secara hakiki dari fenomena yang tampak. Sungguh pun demikian, sistem simbol dapat pula dipahami sebagai sistem penandaan, artinya, kehadiran tak lepas dari beberapa aspek yang dapat dilihat secara terperinci antara lain: gerak, iringan, tempat, pola lantai, tata pakaian dan rias...mengandung makna harafiah, bersifat primer, dan langsung ditunjukkan menurut kesepakatan atau konvensi yang dibentuk secara bersama oleh masyarakat atau budaya di mana simbol atau tanda itu berlaku, demikian penegasan Sumandiyo Hadi (2005:23-24).

\section{Semiotika}

Semiotika adalah suatu ilmu atau metode analisis untuk mengkaji tanda. Tanda-tanda adalah perangkat yang kita pakai dalam upaya berusaha mencari jalan di dunia ini, ditengah-tengah manusia dan bersama-sama manusia. Semiotika, atau dalam istilah Barthes, semiologi, pada dasarnya hendak mempelajari bagaimana kemanusiaan (humanity) memaknai hal-hal (things). Memaknai (to sinify) dalam hal ini tidak dapat dicampur adukkan dengan mengkomunikasikan (to communicate). Memaknai berarti bahwa objek-objek tidak hanya membawa informasi, dalam hal mana objek-objek itu hendak berkomunikasi, tetapi juga mengkonstitusi sistem terstruktur dari tanda. Tandatanda tersebut kemudian dimaknai sebagai wujud dalam memahami kehidupan. Manusia melalui kemampuan akalnya berupaya berinteraksi dengan menggunakan tanda sebagai alat untuk berbagai tujuan, salah satu tujuan tersebut adalah untuk berkomunikasi dengan orang lain sebagai bentuk 64 | Marlina, Sapta Sari, Bayu Risdiyanto, MAKNA SIMBOL DALAM PERTUNJUKAN PENCAK SILAT PADA ACARA 
adaptasi dengan lingkungan. Contoh semiotika dalam kehidupan sehari-hari : Mengacungkan jempol kepada kawan kita yang berprestasi.

Prinsip Semiotika Menurut Roland Barthes Roland Barthes adalah penerus pemikiran Saussure. Saussure tertarik pada cara kompleks pembentukan kalimat dan cara bentuk-bentuk kalimat menentukan makna, tetapi kurang tertarik pada kenyataan bahwa kalimat yang sama bisa saja menyampaikan makna yang berbeda pada orang yang berbeda situasinya. Roland Barthes meneruskan pemikiran tersebut dengan menekankan interaksi antara teks dengan pengalaman personal dan kultural penggunanya, interaksi antara konvensi dalam teks dengan konvensi yang dialami dan diharapkan oleh penggunanya. Barthes menjadi tokoh yang begitu identik dengan kajian semiotik. Pemikiran semiotik Barthes bisa dikatakan paling banyak digunakan dalam penelitian. Konsep pemikiran Barthes terhadap semiotik terkenal dengan konsep mythologies atau mitos. Sebagai penerus dari pemikiran Saussure, Roland Barthes menekankan interaksi antara teks dengan pengalaman personal dan kultural penggunanya, interaksi antara konvensi dalam teks dengan konvensi yang dialami dan diharapkan oleh penggunanya.

Konsep pemikiran Barthes yang operasional ini dikenal dengan Tatanan Pertandaan (Order of Signification). Secara sederhana, kajian semiotik Barthes bisa dijabarkan sebagai berikut : (Kriyantono, 2007 : 268)

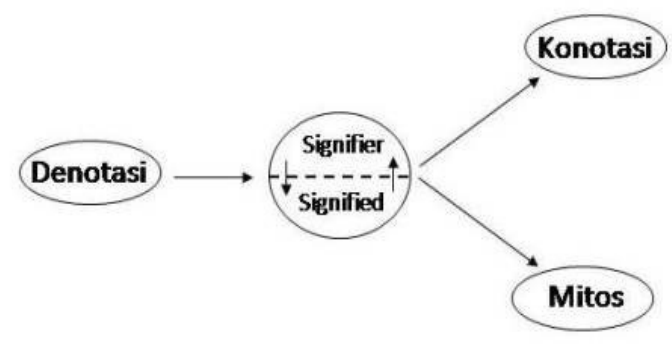

Setelah terbentuk sistem sign-signifier-signified, tanda tersebut akan menjadi penanda baruyang kemudian memiliki petanda kedua dan membentuk tanda baru. Jadi, ketika suatu tandayang memiliki makna konotasi kemudian berkembang menjadi makna denotasi, maka makna denotasi tersebut akan menjadi mitos.

a. Denotasi, Tatanan pertama ini merupakan landasan kerja Saussure. Tatanan ini menggambarkan relasi antara penanda dan petanda didalam tanda dan antara dengan referennya dalam realitas eksternal.

b. Konotasi, Konotasi digunakan untuk menjelaskan salah satu dari tiga cara kerja dalam petandaan kedua. Konotasi menggambarkan interaksi yang berlangsung tatkala tanda bertemu dengan perasaan atau emosi penggunaannya dan nilai-nilai kulturalnya. Ini terjadi tatkala makna bergerak menuju subjektif atau setidaknya intersubjektif. Dalam konsep Barthes, tanda konotatif tidak sekadar memilki makna tambahan namun 
juga mengandung kedua tanda denotatif (penanda dan petanda) yang melandasi keberadaannya.

c. Mitos, Kata mitos berasal dari bahasa Yunani mythos "kata"dan "ujaran". Menurut Barthes mitos disini sebagai sesuatu yang orisinal. Atau dalam kata lain mitos adalah cerita yang digunakan suatu kebudayaan untuk menjelaskan atau memahami beberapa aspek dari realitas atau alam. Bagi Barthes, mitos merupakan cara berpikir dari suatu kebudayaan tentang sesuatu, cara untuk mengkonseptualisasikan atau memahami sesuatu dan juga memahami secara lebih baik nilai-nilai yang mengikat para anggota masyarakat untuk menjadi suatu kelompok. Mitos dapat dibandingkan untuk mengetahui bagaimana kebudayaan dapat saling berbeda atau menyerupai satu sama lain, dan mengapa orang bertingkah laku seperti itu. Kajian mitos juga dapat dijadikan kerangka referensi yang mendasari tidak hanya karya- karya besar di bidang arsitektur, sastra, musik, lukisan, dan seni pahat, tetapi juga hal-hal kontemporer seperti iklan dan program televisi.

\section{Pencak Silat}

Secara Etimologi Pencak Silat berasal dari dua kata yaitu Pencak dan Silat. Istilah Pencak sudah terkenal di daerah Asia tenggara sedangkan Silat hanya dikenal di Indonesia. Kata Pencak dan Silat memilikiarti yang sama namun dalam perkembanganya, Pencak lebih mengarah ke seni bela diri sedangkat silat mengarah ke ajaran beladiri atau pertarungan. Jadi menurut Hasan Alwi dkk, (2008:1043) disimpulkan bahwa Pencak silat adalah kepandaian berkelahi, seni beladiri khas Indonesia dengan ketangkasan membela diri dan menyerang untuk petandingan atau perkelahian dan untuk pertunjukan. Peristiwa panggung bukanlah peristiwa yang sebenarnya, melainkan peristiwa simbolis yang diangkat dari pengalaman kehidupan manusia. Apa yang terjadi dan diperagakan semata-mata adalah simbolisasi dari pesan-pesan seniman untuk mengkomunikasikan gagasangasasan atau ide-ide keseniannya.

Kesenian daerah yang tumbuh dan berkembang di Desa tengah padang yaitu Kesenian Pencak Silat, Kesenian dapat diartikan sebagai hasil karya manusia yang mengandung keindahan dan dapat diekspresikan melalui suara, gerak ataupun ekspresi lainnya, Kesenian memiliki banyak jenis bila dilihat dari perkembangannya didalam gerakan pencaksilat suku lembak ini mempunyai makna tersendiri yaitu :

1. Salam-salam dengan kedua mempelai dan menunduk kepala yang berarti meminta restu agar pertunjukan pencak silat berjalan dengan lancar dan sukses.

2. Pencak Silat Di lakukan dan diawali dengan kemanten laki-laki lalu di pertengahan acara diganti dengan pendamping atau anggota pencak silat sampai acara selesai.

3. kaki diinjit dan tangan memegang pedang sambil di goyang-goyang supaya lawan mengetahui bahwa lawan satunya menentang untuk lawan bias menangkis.

66 | Marlina, Sapta Sari, Bayu Risdiyanto, MAKNA SIMBOL DALAM PERTUNJUKAN PENCAK SILAT PADA ACARA 


\section{Suku Lembak}

Suku Lembak adalah suku asli Bengkulu, Bahasa buang yang masi serumpun dengan bahasa melayu, suku lembak terbagi menjadi 2 (dua) bagian, yaitu Lembak Beliti dan Lembak Delapan. Orang lembak memiliki tulisan asli yang disebut surat ulu seperti halnya suku serawai, suku lembak, kelingi berkemukim di pedalaman Bengkulu, yaitu diulu sungai musi Bengkulu dan Sumatra selatan dengan pola perkampungan yang mengelompok padat. Suku Lembak Beliti adalah suku bangsa yang pemukimannya tersebar di kota Bengkulu, Bengkulu Utara, kabupaten Bengkulu Tengah kabupaten Rejang Lebong, dan kabupaten Kepahiang.

Suku Lembak di kabupaten Rejang Lebong bermukim di kecamatan Padang Ulak Tanding, Sindang Kelingi, dan Kota Padang. Di kabupaten Bengkulu Tengah, suku Lembak mendiami desa Kecamatan Talang Empat. Pencak adalah permainan (keahlian) untuk mempertahankan diri dengan kepandaian menangkis, mengelak, dan sebagainya sedangkan Silat adalah olahraga (permainan) yang didasarkan pada ketangkasan menyerang dan membela diri, dengan memakai atau tanpa senjata. (Hasan Alwi dkk, 2008:1306)

Suku lembak juga mendiami wilayah daerah Kota Lubuk linggau dan kabupaten Musi Rawas yang berada di wilayah provinsi Sumatera Selatan. Di Desa Tengah Padang Kecamatan Talang Empat Kabupaten Bengkulu Tengah orang Lembak menyebut bahasa mereka bahasa Bulang yang masih termasuk rumpun bahasa Melayu. Kata Lembak ada beberapa arti. Ada yang mengartikan "lembah", dan juga "lebak", yaitu daratan sepanjang aliran sungai, dan adapula yang mengartikan "belakang". orang Lembak menyebut bahasa mereka bahasa Bulang yang masih termasuk rumpun bahasa Melayu. Ciri yang menonjol dari bahasa Bulang ini adalah pemakaian vokal "e" untuk menggantikan vokal "a" di belakang sebuah kata. Misalnya apa diucapkan "ape", ke mana diucapkan "kemane", siapa menjadi "siape" dan seterusnya. Pada zaman dulu mereka menggunakan aksara yang sama dengan aksara suku bangsa Rejang dan Serawai. Aksara ini mereka sebut surat ulu. Budaya Suku Lembak adalah pemeluk agama Islam sehingga kebudayannya banyak bernuansakan Islam, disamping itu masih ada pengaruh dari kebudayaan lainnya. Dari sisi adat-istiadat antara melayu bengkulu dan suku lembak ada terdapat kesamaan dan juga perbedaan

\section{Pernikahan Atau Perkawinan Suku Lembak}

Menurut Ahmad Ashar Bashir Pernikahan adalah melakukan suatu akad atau perjanjian untuk mengikatkan diri antara seorang laki-laki dan wanita untuk menghalalkan hubungan kelamin antara kedua belah pihak, dengan dasar sukarela dan keridhaan kedua belah pihak untuk mewujudkan suatu kebahagiaan hidup berkeluarga yang diliputi rasa kasih sayang.

Menurut Zahry Hamid Perngertian Pernikahan atau Perkawinan yaitu merupakan akad (ijab kabul) antara wali dan mempelai laki-laki dengan ucapan tertentu dan memenuhi rukun dan syaratnya. Dalam Pengertian Pernikahan secara umum adalah suatu ikatan lahir batin antara seorang laki-laki dan seorang perempuan untuk hidup berketurunan, yang dilangsungkan menurut 
ketentuan syariat islam. Dalam suku lembak ini pakaian yang dipakai adalah pakaian adat bengkulu, dimna adat bengkulu itu pengantin laki-laki memakai tuguk luncuk (kain yang di lipat yang bentuknya memanjang) begitu juga dengan inang laki-lakinya, sedangkan pihak perempauan dan apitnya tidak menggunakan pakaian serupa. Pemilihan jodoh pada adat suku bangsa Lembak masa kira-kira sebelum tahun 1950-an masih didominasi oleh keinginan orang tua (bapak, ibu atau ahli laki-laki atau perempuan), dikenal dengan istilah rasan tue. Kemudian ada juga pemilihan jodoh tersebut diungkapkan oleh sianak karena tertarik kepada seseorang yang disampaikan kepada orang tuanya, bila orang tua berkenan maka keinginan akan dilanjutkan, bila orang tua tidak berkenan maka orang tua tidak akan melanjutkan. Walaupun dominasi orang tua masih kuat namun biasanya pada Adat Suku Lembak masih banyak orang tua menanyakan terlebih dahulu kepada anaknya untuk mengungkapkan hasratnya untuk menjodohkan dengan si anu anak si anu. Namun sesunggunya menanyakan kepada anak tersebut sebenarnya penekanan lebih terarah pada pemberitahuan saja, hal itu dikarenakan dominsai orang tua lebih dominan. Dari kedua bentuk pemilihan jodoh tersebut baik dominasi orang tua maupun anak menyampaikan hasratnya kepada orang tua, proses yang dilakukan tetap dimulai dari menindai (mengamati dan mengevaluasi). Kondisi dominasi orang tua tersebut dimungkinkan pada saat itu belum adanya media yang lebih leluasa bagi pasangan muda-mudi untuk bertemu dan bergaul, secara lebih dekat

\section{Kerangka Pemikiran}

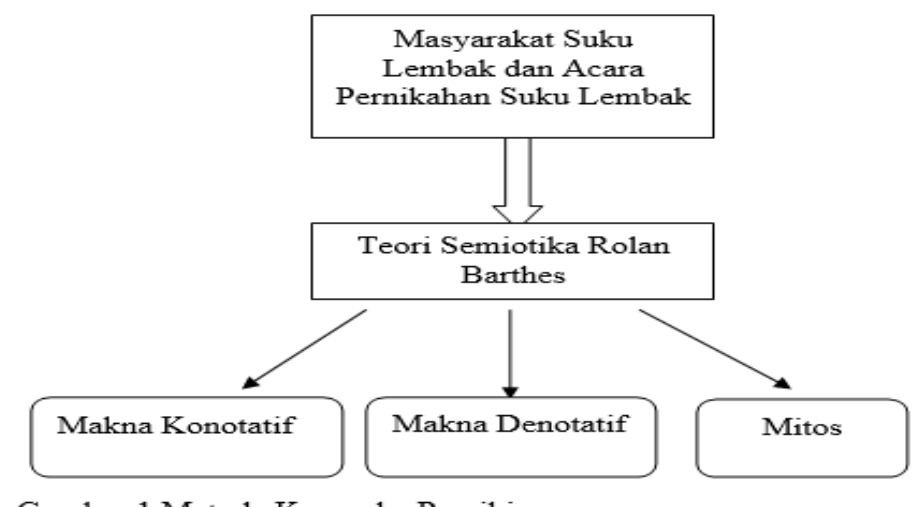

Gambar 1 Metode Kerangka Pemikiran

\section{METODE PENELITIAN}

Jenis penelitian yang digunakan dalam penelitian ini adalah deskriptif kualitatif . metode penelitian kualitatif dengan menggunakan metode semiotka Roland Barther. Menurut Sugiyono (2005: 1) penelitian Kualitatif adalah metode penelitian yang digunakan untuk menelitipada kondisi ofjek yang alamiah ( sebagai lawannya adalah eksperimen ) dimana peneliti adalah instrument kunci. Penelitian deskriptif kualitatif menafsirkan dan menuturkan data yang 
bersangkutan dengan situasi yang sedang terjadi, sikap serta pandangan yang terjadi di dalam Pertunjukan Pencaksilat di Desa Tengah Padang Kabupaten Bengkulu Tengah.

Untuk menggali data yang berkaitan Makna Simbol Dalam Pertunjukan Pencak Silat Pada Acara Pernikahan Suku Lembak berdasarkan teknik informan dengan Purposive Sampling yaitu orang yang benar-benar mengetahui apa yang akan diteliti dan terlibat langsung dan bersedia memberikan informasi tentang masala yang diangkat oleh peneliti terdapat 3 (tiga) orang informan yang dijadikan objek penelitian. Dari keseluruhan informan ini, merupakan mereka yang terkait dengan kegiatan yang diteliti serta memiliki waktu yang cukup untuk member informasi. Dengan demikian peneliti mengambil beberapa informan dengan teknik purposive Sampling yaitu orang yang benar-benar mengetahui tentang Pencak Silat Di Suku Lembak.

\section{HASILDAN PEMBAHASAN}

\section{Metode Analisis Roland Barthes Mengenai Makna Pesan Pertunjukan Pencak Silat Didalam Acara Pernikahan Suku Lembak}

Kebudayaan yang ada pada Masyarakat dalam melakukan acara adat Pernikahan itu sangatlah penting. Masyarakat melakukan berbagai rangkayan adat dalam sebuah Pernikahan sesuai dengan adat yang dimilikimdari setiap daerah/ suku khusus di Desa Tengah Padang Kecamatan Talang Empat Kabupaten Bengkulu Tengah yang memiliki beragam suku, Khusus Suku Lembak. Pandangan masyarakat mengenai keberadaan beladiri pencak silat diera modern berkaitan dengan budaya warisan leluhur, dimana budaya pencak silat ini harus di lestarikan dan dipertahankan. Rasa kehawatiran masyarakat terhadap kelestarian pencak silat adalah seringnya pencak silat digunakan pada hal-hal yang bersifat negatif. Yang dampaknya ketika mempelajari pencak silat menjadi suatu hal yang dilarang. makna pencak silat didalam acara pernikahan suku lembak ini, untuk diri sendiri selain itu juga bisa menghibur orang banyak, salah satunya untuk melestarikan suku adat dan alat mempersatu, Masih bersifat sementara apa bila dilakukan itu lebih baik dan jika tidak dilakukan juga tidak apa-apa.

Sesuai dengan teori yang dipakai didalam acara pernikahan Suku Lembak, Adat Istiadat Desa Tengah Padang ini melakukan tarian pencak silat ini terbagi menjadi 3 (tiga) bagian yaitu : gerakan awal, gerakan inti dan gerakan penutup. Nama Alat- alat yang digunakan untuk Tarian Pencak Silat yaitu : Pedang, Rabana, Kelentang,dan Serunai.

Kebudayaan yang ada pada masyarakat dalam melakukan acara pernikahan sangat penting. Masyarakat melakukan berbagai rangkayan adat dalam pernikahan sesuai dengan adat yang dimiliki, didalam acara pernikahan Suku Lembak Adat Istiadat Desa Tengah Padang ini melakukan tarian pencak silat, Sebelumnya kedua mempelai di arak arak dengan diiringi Rabana, Sesudah di arak-arak kedua mempelai sujud meminta restu kepada Ketua Pencak Silat, Ketua Adat Dan Tokoh-Tokoh Agama agar acara berjalan dengan sukses lancar. 
Berdasarkan hasil Obserpasi awal dan wawancara para penelitian dengan beberapa orang masyarakat Tengah Padang maka makna pencak silat didalam acara pernikahan suku lembak ini, untuk diri sendiri selain itu juga bisa menghibur orang banyak, salah satunya untuk melestarikan suku adat dan alat mempersatu, Masi bersipat sementara apa bila dilakukan itu lebih baik dan jika tidak dilakukan juga tidak apa-apa. Makna Konotatif, Makna Denotatif, dan Mitos Pada gerarakan Pencak Silat Yaitu:

\section{Gerakan Awal.}

A. Makna Konotatif : Jabatan tangan

Makna Denotatif : Terdahulu Jabatan tangan atau sembah sujud dengan Ketua Adat, Guru Pencak Silat dan orang yang mengadakan acara tersebut. Gerakan di awali dengan mempelei laki-laki, apabila mempelai laki-laki tidak sanggup maka di sambung dengan pengasuh atau inang mempelai laki-laki.

Mitos : Menghormati Leluhur agar acara berjalan dengan lancer dan lebih sempurna

B. Makna Konotatif : Mempelai memakai baju adat

Makna Denotatif : Pencak Silat ini diawali dengan mempelai laki - laki yang memakai baju Adat Suku Lembak, semua nya untuk melambangkan Adat Istiadat Suku Lembak tersebut.

Mitos : Melambang kan bahwa kedua mempelai benar -benar berasal dari suku lembak.

C. Makna Konotatif :Serunai, Rabana, dan Kelentang

Makna Denotatif : Serunai, Rabana, dan Kelentang ini adalah alat -alat untuk Acara Pencak Silat Suku Lembak, ketiga alat ini sangat la penting di dalam acara pencaksilat karena alat-alat ini untuk menghidupkan gerakan-gerakan yang mereka lakukan sehingga menjadi seiramah, lebih indah, lembut dan lebih menarik.

Mitos : Turun temurun, Dari nenek Moyang

\section{Gerakan inti}

A. Makna Konotatif : Pedang dan menggunakan gerakan tangan

Makna Denotatif : Gerakan inti ini yang diawali dengan memegang pedang, Tangan yang digelitik, dan pedang di putar-putar, kemudian diarahkan dengan lawan gerakan ini untuk memancing emosi pihak lawan. Lida di keluarkan, kaki di injit dan di angkat semuanya ini hanya untuk memeriakan acara dan untuk memancing emosi pihak lawan apa bila lawan sudah terpancing emosi maka Gerakan yang ditampilkan akan lebih menarik

Mitos : Menarik perhatian lawan agar lawan merasa emosi

B. Makna Konotatif : Gerakan Kaki dan tubuh

Makna Denotatif : Gerakan ini menggunakan gerakan kaki, yang kaki nya di injit dan di angkat, Lida di keluarkan. Dan gerakan - gerakan yang lucu supaya penonton lebih terhibur dan untuk memeriakan acara dan untuk memancing

70 | Marlina, Sapta Sari, Bayu Risdiyanto, MAKNA SIMBOL DALAM PERTUNJUKAN PENCAK SILAT PADA ACARA 
emosi pihak lawan apa bila lawan sudah terpancing emosi maka pertunjukan Pencak Silat ini akan menjadi lebih menarik

Mitos : Menarik perhatian lawan agar lawan merasa emosi

C. Makna Konotatif : Lemuai Atau Kapur Sirih

Makna Denotatif : Lemuai atau kapur sirih ini adalah lambang dari Adat Istiadat Suku Lembak, Yang di atas mejah di antara anggota pencaksilat yang satu dengan yang satunya lagi maka ini dinamakan meja pembatas apa bila salah satu anggota pencaksilat melewati meja pembatas maka akan terkena sangsi Adat yang telah ditentukan dengan Ketua Adat.

Mitos : Menarik perhatian lawan agar lawan merasa emosi anggota pencak silat melewati meja pembatas maka akan terkena sangsi Adat.

\section{Gerakan Penutup}

A. Makna Konotatif : Sembah Sujud

Makna Denotatif : Gerakan pedang di letakkan ketanah dan tangan melambailambai untuk menutup acara.

Mitos : Cara menghormati tetamu dan para guru turun menurun

B. Makna Konotatif : Sembah Sujud

Makna Denotatif : kedua mempelai di persilahkan berjalan menuju ke pelaminan sambil sembah sujud dengan anggota Pencak Silat dan Ketua Adat, dan kedua mempelai dipersilahkan duduk di pelaminan.

Mitos : Cara menghormati tetamu dan para guru turun menurun

\section{KESIMPULAN DAN SARAN}

\section{Kesimpulan}

Berdasarkan hasil penelitian dan pembahasan yang telah dikemukakan, maka dalam penelitian yang berjudul "Makna Simbol Dalam Pertunjukan Pencak silat Pada Acara Pernikahan Suku Lembak. Masyarakat Mempelajari Ilmu Pencak Silat di Era Modern Pada Masyarakat Desa Tengah Padang Kecamatan Talang Empat Kabupaten Bengkulu Tengah" dapat diambil beberapa kesimpulan sebagai berikut: Didalam acara Pencak Silat ini Mempunyai tiga gerakan yaitu gerakan awal gerakan inti dan gerakan penutup. Makna Konotatif di acara pencaksilat di dalam gerakan awal yaitu :

a. Jabatan Tangan untuk menghormati Leluhur agar acara berjalan dengan lancer

b. Mempelai di Dalam Pencaksilat Memakai Baju Adat ,yang melambangkan bahwa mempelai laki-laki benar-benar dari Suku Lembak.

c. Serunai Rabana dan Kelentang alat dari Pencak Silat yang turun menurun dari nenek moyang. Makna Konotatif di acara pencaksilat di dalam gerakan Inti

1) Pedang Dan menggunakan gerakan tangan yang bertujuan untuk menarik perhatian lawan 
2) Gerakan kaki dan tubuh gerakan ini semua hanya untuk menarik perhatian lawan supaya lawan ber semangat untuk melawan

3) Lemuai atau Kapur Sirih alat ini turun menurun dan sikapur sirih untuk meja pembatas apabila anggota Pencak Silat Melanggar maka terkena sangsi Adat

Makna Konotatif di acara pencak silat di dalam gerakan Penutup :

a. Sembah Sujud memakai Pedang ini salah satu untuk menutup acara Pencak Silat.

b. Sembah Sujud Dengan Jabatan Tangan ini semua gerakan untuk menghormati Tetamu dan Guru Turun Menurun

Seni Pencak silat ini mempunyai meja pembatas yang diatasnya ada Lemuai apa bila salah satu peserta melewati pembatas maka akan mendapatkan sangsi adat yang telah di tentukan dengan Adat istiadat Suku Lembak. Mitos di dalam acara Pencak Silat, ini semuah kegiatan turun menurun dari nenek moyang orang Suku Lembak dan bisa diartikan salah satu Menghormati Leluhur,Agar acara berjalan dengan sempurna.

\section{Saran}

Adapun saran yang dapat diberikan adalah :

1. Bagi Pemerintah Daerah Kabupaten Bengkulu Tengah husus Desa Tengah Padang untuk lebih memperhatikan dan melestarikan kesenian daerah agar terjaga keasliannya dan tidak punah, serta melakukan usaha dokumentasi atau pencatatan khusus mengenai sejarah dan perkembangan tarian Pencak Silat yang ada sehingga dapat menambah wawasan kesenian kerakyatan khususnya yang ada di Kabupaten Bengkulu Tengah.

2. Bagi Dinas Kebudayaan dan Pariwisata Kabupaten Bengkulu Tengah, agar ikut membina, mendorong, dan memfasilitasi sarana dan prasarana yang menunjang keberlangsungan tarian Pencak Silat dalam upacara adat perkawinan Di Suku Lembak yang merupakan aset kebudayaan Daerah Kabupaten Bengkulu Tengah.

3. Bagi Desa Tengah Padang hendaknya tetap menjaga dan melestarikan tarian Pencak Silat dan kesenian lainnya serta memberikan pemahaman terhadap makna yang terkandung di dalam tarian Pencak Silat agar terjadi regenerasi sebagai salah satu upaya pelestarian budaya.

4. Bagi mahasiswa, khususnya mahasiswa Pendidikan Komunikasi, hendaknya hasil penelitian ini bisa di jadikan acuan dan referensi penunjang untuk penelitian selanjutnya, serta dapat menambah apresiasi dan wawasan dalam hal kesenian Indonesia, khususnya kesenian dari Bengkulu Tengah. 


\section{DAFTAR PUSTAKA}

Alsan, Alwi dkk .2008. Adat Dan Upacara Perkawinan Daerah Bengkulu. Bengkulu, Departemen Pendidikan dan Kebudayaan.

Efendi. 2003. Bentuk Komunikasi Pribadi Kelompok Kecil Dan Kelompok Besar. Bandung, Alfabeta

Proyek Penelitian Daerah. 1978. Adat Istiadat Daerah Bengkulu. Bengkulu, Depdikbud.

Proyek Penelitian Daerah. 1988. Adat dan Upacara Perkawinan Daerah Bengkulu. Bengkulu. Depdikbud.

Sugiono. 2005. Penelitian Kualitatif. Bandung, Alfabeta

Suku Serawai Kecamatan Seluma Kabupaten Bengkulu Selatan, Padang. 2004 Kebudayaan dan Pariwisata Kabupaten Seluma. Seluma. Dinas Pendidikan Dan Kebudayaan.

Sumandiyo Hadi, 2005 - 2006 tentang pengertian simbol

http://www.kompasiana.com/keretaunto.blogspot.com/mengenal-budaya-suku-

bangsa-serawai-bengkulu-selatan

Credits: http://www.satujam.com/pengertian-pencak-silat/

(Online),(http:Reviewkomunikasi.Blogspot.Com).http:www.Fahmi

zolla.Blogspot.com

Ferdinand desaussure dalam abdul Chaer, 1994 (Budiono,2008) perbedaan symbol dan makna

Mead,(Online),(http:Reviewkomunikasi.Blogspot.Com).http:www.Fahmi

zolla.Blogspot.com 